\title{
Survival of Klebsiella pneumoniae strain borkar in pomegranate orchard soil and its tolerance to temperature and $\mathrm{pH}$
}

\begin{abstract}
The plant pathogenic Klebsiella pneumoniae survived in pomegranate orchard soil for more than two years in an infectious stage. The pomegranate seedlings/grafts planted at a site which had the wilt disease plant earlier and left fallow for a season also succumb to Klebsiella infection causing wilt. The bacterium also survives in root bark necrosis lesions for more than two years under laboratory storage condition.

The plant pathogenic Klebsiella pneumoniae survived at a temperature up to $45^{\circ} \mathrm{C}$ from a low temperature of $5^{\circ} \mathrm{C}$, indicating its surviving ability in temperate and tropical temperature condition. The survival of the bacterium at 7 to $10 \mathrm{pH}$ levels indicates its tolerance to neutral and alkaline condition; however no growth of the bacterium at 2 to $6 \mathrm{pH}$ indicates its intolerance to acidic condition.
\end{abstract}

Special Issue - 2018

\author{
Ajayasree TS, Borkar SG \\ Department of Plant Pathology and Agricultural Microbiology, \\ Mahatma Phule Agriculture University, India \\ Correspondence: Ajayasree TS, Department of Plant \\ Pathology and Agricultural Microbiology, Mahatma Phule \\ Agriculture University, Rahuri- 413722, Dist- Ahmednagar (M.S), \\ India, Email ajayasreeI28@gmail.com, borkarsg@yahoo.co.in
}

Received: June 08, 2018 | Published: September 21, 2018

Keywords: klebsiella pneumoniae, pomegranate, root bark necrosis, survival, soil, plant, enterobacteria

\section{Introduction}

Survival of plant pathogenic bacteria in soil depends on several factors like soil environmental condition, soil's physical and chemical properties, soil's texture and structure, the infected crop residues in soil and the ability of bacteria to survive all these external factors. Perpetuation of the bacteria in soil over a long period makes the soil uncultivable for that crop, helps in spread of disease and its intensities year after year and a cause for substantial yield losses. ${ }^{1}$

The root bark necrosis and wilt of pomegranate, a new bacterial disease in this crop, caused by soil borne enterobacteria Klebsiella pneumoniae is assuming significance as the infected plant die and does not revive. The infected plants in the orchard has to be uprooted and destroyed as a remedial measures; however the new plantation of pomegranate done in such orchards also succumbed to the infection of the same bacteria surviving in the orchard. What is the survival period of this bacterial pathogen in the soil is not yet known. Therefore survival of Klebsiella pneumoniae strain Borkar in pomegranate orchard soil and its tolerance to temperature and $\mathrm{pH}$ was studied so as to formulate the management strategies.

\section{Materials and methods}

\section{Detection of Klebsiella pneumoniae from infected orchard soil}

The soil samples were collected from fallow soil which previously had the root bark necrosis and wilt disease of pomegranate where the diseased plants were uprooted and destroyed. The soil samples were collected from a $30-45 \mathrm{~cm}$ soil depth and brought to laboratories.

$10 \mathrm{~g}$ soil sample was dissolved in $25 \mathrm{ml}$ sterile water and shaken vigorously. This was centrifuged in table top centrifuge at 5000rpm to settle the soil particles. The supernatant was filtered through Whitman filter paper-24 to remove the eukaryotic microbes. The filtrate was used for detection of Klebsiella pneumoniae. A loopful of filtrate was streaked on nutrient media in triplicate plates and incubated at $30^{\circ} \mathrm{C}$ temperature for 5 days. Colonies obtained in the isolation plates were further purified to obtain the pure culture of the bacterium. Observation for the frothing bacterial culture (Figure 1) characteristic of Klebsiella pneumoniae was taken.

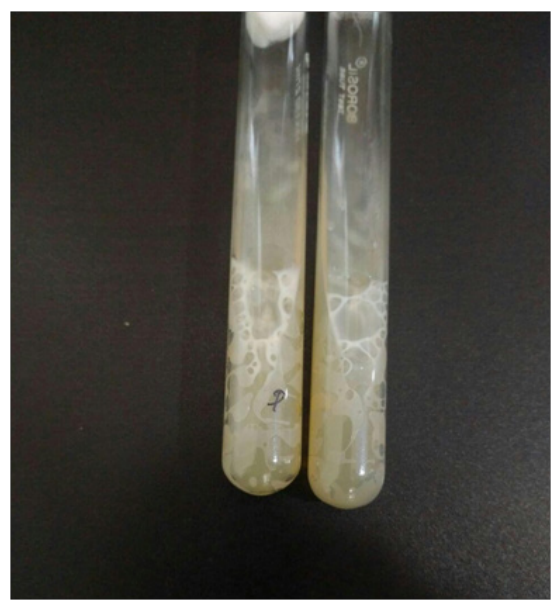

Figure I Frothing of Klebsiella pneumoniae in pure culture NAS slant.

The soil samples were taken from the fallow pomegranate orchard at a monthly interval for more than 2 years and used for the detection of Klebsiella pneumoniae as described above.

\section{Detection of Klebsiella pneumoniae from infected root bark necrosis lesions}

The root samples infected with root bark necrosis lesions were collected from wilted pomegranate plant. The samples were stored at ambient temperature in laboratory and used for detection of Klebsiella pneumoniae bacteria at an interval of a month. 
The root bark necrosis sample was surface sterilized with mercuria chloride $(0.1 \%)$, washed thrice in distilled water and macerated in pestle and mortar in $5 \mathrm{ml}$ distilled sterile water and left as such for 5 minutes. An aliquot of the supernatant $(0.2 \mathrm{ml})$ was plated on the nutrient agar plates and incubated at $30 \pm 2^{\circ} \mathrm{C}$ temperature for 5 days. Observations for the frothing bacterial colonies characteristic of Klebsiella pneumoniae were taken.

The experimentation for detection of Klebsiella pneumoniae from the infected root sample was carried out for more than 2 years.

\section{Tolerance of Klebsiella pneumoniae to different temperatures}

The Klebsiella pneumoniae bacterial suspension was prepared aseptically and added to sterile glass vial at $5 \mathrm{ml}$ quantities. The individual vial was marked with respective temperature. These vials containing Klebsiella suspension were immersed in water of a particular temperature maintained in hot water bath (the variation in temperature of water in hot water bath and inside the glass vial was calculated and adjusted accordingly, the water temperature below the ambient was adjusted by adding ice-cold/cold water). The bacterial suspension was exposed to the respective temperature for 10minutes and loopful of suspension from this was streaked on nutrient agar media. The plates were incubated in BOD incubator at $30^{\circ} \mathrm{C}$ temperature for 5 days to observe the frothing colonies characteristic to Klebsiella pneumoniae. The temperature range tested was from $5^{\circ} \mathrm{C}$ to $45^{\circ} \mathrm{C}$ temperature.

\section{Tolerance of Klebsiella pneumoniae to different pH}

$15 \mathrm{ml}$ nutrient broth of different $\mathrm{pH}$ concentrations viz. 2, 3, 4, 5, $6,7,8,9$ and 10 was prepared and sterilized in $25 \mathrm{ml}$ individual flask marked with particular $\mathrm{pH}$. These flasks were inoculated with $1 \mathrm{ml}$ of Klebsiella suspension and incubated at $30^{\circ} \mathrm{C}$ temperature for 48 hours.

A loopful of growth suspension from these respective $\mathrm{pH}$ flasks were streaked on a nutrient agar plate marked with that $\mathrm{pH}$ concentration and incubated for 5 days at $30^{\circ} \mathrm{C}$ to observe the frothing colonies characteristic to Klebsiella pneumoniae.

\section{Results}

The result (Table 1) indicates that the root bark necrosis bacteria survive in pomegranate orchard soil for more than two years. Similarly, the bacteria survive in root bark necrosis lesions more than two years.

Table I Survival of Klebsiella pneumoniae strain Borkar in pomegranate orchard soil and infected diseased material

\begin{tabular}{|c|c|c|c|c|c|c|c|c|c|c|c|c|c|c|c|c|c|c|c|c|c|c|c|c|c|}
\hline \multirow{2}{*}{$\begin{array}{l}\text { Sr. } \\
\text { No. }\end{array}$} & \multirow{2}{*}{$\begin{array}{l}\text { Infected } \\
\text { material }\end{array}$} & \multicolumn{24}{|c|}{ Survival (in months) of Klebsiella pneumoniae strain Borkar } \\
\hline & & I & 2 & 3 & 4 & 5 & 6 & 7 & 8 & 9 & 10 & I I & 12 & 13 & 14 & 15 & 16 & 17 & 18 & 19 & 20 & 21 & 22 & 23 & 24 \\
\hline I & $\begin{array}{l}\text { In } \\
\text { infected } \\
\text { orchard } \\
\text { soil }\end{array}$ & + & + & + & + & + & + & + & + & + & + & + & + & + & + & + & + & + & + & + & + & + & + & + & + \\
\hline 2 & $\begin{array}{l}\text { In root } \\
\text { bark } \\
\text { necrosis } \\
\text { lesion }\end{array}$ & + & + & + & + & + & + & + & + & + & + & + & + & + & + & + & + & + & + & + & + & + & + & + & + \\
\hline
\end{tabular}

The result (Table 2) on temperature tolerance indicates that the bacteria survives at a temperature up to $45^{\circ} \mathrm{C}$ from a low temperature

of $5^{\circ} \mathrm{C}$, indicating its surviving ability in temperate and tropical temperature.

Table 2 Tolerance of Klebsiella pneumoniae strain Borkar to different temperature

\begin{tabular}{|c|c|c|c|c|c|c|c|c|c|c|}
\hline $\begin{array}{l}\text { Sr. } \\
\text { No. }\end{array}$ & Survival of Kle & iella & eumo & ae str & n Borl & & & & & \\
\hline \multirow{2}{*}{ I } & At tomon & $5^{\circ} \mathrm{C}$ & $10^{\circ} \mathrm{C}$ & $15^{\circ} \mathrm{C}$ & $20^{\circ} \mathrm{C}$ & $25^{\circ} \mathrm{C}$ & $30^{\circ} \mathrm{C}$ & $35^{\circ} \mathrm{C}$ & $40^{\circ} \mathrm{C}$ & $45^{\circ} \mathrm{C}$ \\
\hline & & + & + & + & + & + & + & + & + & + \\
\hline
\end{tabular}

The result (Table 3 ) indicates that the bacteria survive to the $\mathrm{pH}$ concentration of 7 to $10 \mathrm{pH}$ indicating its tolerance to neutral and alkaline condition; however no growth of the bacterium at $\mathrm{pH} 2$ to 6 indicates its intolerance to acidic condition.

Table 3 Tolerance of Klebsiella pneumoniae strain Borkar to different $\mathrm{pH}$.

\section{Sr. No Survival of Klebsiella pneumoniae strain Borkar}

\begin{tabular}{lllllllllll}
\hline & At pH & 2 & 3 & 4 & 5 & 6 & 7 & 8 & 9 & 10 \\
& - & - & - & - & - & - & - & - & - \\
\hline
\end{tabular}

\section{Discussion}

The plant pathogenic soil bacteria are known to survive in the infected soil samples for various durations. Ralstonia solanacearum survive in soil for up to 2 years, ${ }^{2}$ Erwinia caratovora survive in soil for one and a half years ${ }^{3}$ while Clavibacter michiganensis survive in soil for 2 years. ${ }^{4}$

The plant pathogenic Klebsiella pneumoniae survive in pomegranate orchard soil for more than two years in an infectious stage. The pomegranate seedling/graft planted at a site which had the wilt diseased plants earlier and were left fallow for a season 
also succumbs to Klebsiella infection causing wilt. The bacterium also survives in root bark necrosis lesions on root for more than two years under ambient conditions. Perpetuation of bacteria in soil and infected root samples over a long period makes the soil uncultivable for pomegranate crop and helps in spread of disease and its intensities year after year and mortalities in pomegranate plants.

Broadbent et al. ${ }^{5}$ reported that Pseudomonas usually did not survive at $50^{\circ} \mathrm{C}$ for $10 \mathrm{~min}$. The effect of $\mathrm{pH}$ was studied by Michel $\& \mathrm{Mew}^{6}$ on Ralstonia solanacearum. The population of Ralstonia solanacearum was reduced at $\mathrm{pH} 9$. The klebsiella pneumoniae survive and tolerate up to $45^{\circ} \mathrm{C}$ temperatures from a low temperature of $5^{\circ} \mathrm{C}$, indicating its surviving ability in temperate and tropical temperature. The Klebsiella pneumoniae tolerates a $\mathrm{pH}$ concentration from 7 to $10 \mathrm{pH}$, indicating its tolerance to both neutral and alkaline conditions; however the bacterium was intolerant to $\mathrm{pH}$ concentration of 2 to $6 \mathrm{pH}$ indicating its intolerance to acidic condition.

\section{Conclusion}

The plant pathogenic Klebsiella pneumoniae which causes root bark necrosis and wilt in pomegranate survive in pomegranate orchard soil for more than 2 years. It tolerates temperature up to $45^{\circ} \mathrm{C}$ and both to neutral and alkaline $\mathrm{pH}$ conditions. However the bacterium is intolerant to acidic condition of $\mathrm{pH} 2$ to 6. Klebsiella pneumoniae is a new soil borne plant pathogenic bacteria and its survival period in soil, its temperature and $\mathrm{pH}$ tolerance will help to formulate its management strategies.

\section{Acknowledgement}

None.

\section{Conflict of interest}

The authors declare that there is no conflict of interest.

\section{References}

1. Buddenhagen IW. The relation of plant pathogenic bacteria to the soil. In Baker KF, Synder WC, editors. Ecology of Soil borne plant pathogens. Univ of Calif. Press, USA: Berkeley; 1965. p. 269-284.

2. Stander EIM, Hammes PS, Beyers EA. Survival of Ralstonia solanacearum biovar 2 in soil under different cropping systems. S Afr J plant soil. 2003;20(4):176-179.

3. Perombelon MCM, Hyman LJ. Survival of soft rot coliforms, Erwinia caratovora subsp. Caratovora and Erwinia caratovora subsp atroseptica in soil in Scotland. J Appl Microbiol. 1989;66:95-106.

4. Fatmi M, Schaad NW. Survival of Clavibacter michiganensis subsp michiganensis in infected tomato stem under natural field conditions in California, Ohio and Morocco. Plant Pathology. 2002;51:149-154.

5. Broadbent P, Baker KF, Waterworth Y. Bacteria and actinomycetes antagonistic to fungal root pathogens in Australian soils. Aust J Biol Sci. 1971;24(5):925-944.

6. Michel VV, Mew TW. Effect of soil amendment on the survival of Ralstonia solanacearum in different soils. Phytopathology. 1998;88(4):300-305. 